\title{
COMPLEX USAGE OF 4D INFORMATION MODELLING CONCEPT FOR BUILDING DESIGN, ESTIMATION, SHEDULING AND DETERMINATION OF EFFECTIVE VARIANT
}

\author{
Vladimir Popov ${ }^{1}$, Saulius Mikalauskas², Darius Migilinskas ${ }^{3}$, Povilas Vainiūnas ${ }^{4}$ \\ 1, ${ }^{4}$ Department of Reinforced Concrete and Masonry Structures, Vilnius Gediminas Technical University, \\ Sauletekio al.11,LT-10223 Vilnius, Lithuania.E-mail: gel@st.vtu.lt \\ ${ }^{2}$,Statybos ekonominiai skaičiavimai“ Author Group, \\ Birželio 23-iosios g. 23F,LT-50220 Kaunas, Lithuania.E-mail: saulius.mikalauskas@ses.lt \\ ${ }^{3}$ Department of Construction Technology and Management, Vilnius Gediminas Technical University \\ Sauletekio al. 11,LT-10223 Vilnius, Lithuania.E-mail: dariusmg@mail.lt
}

Received 10 March 2006; accepted 15 June 2006

\begin{abstract}
With the growth of information technologies in the field of construction industry, the concept of CAD (Computer Aided Design), which denotes just design operations using a computer acquires a new meaning and changes the contents lightening design process based on product modelling and further numerical simulation construction process and facility managing. New definitions as Building Information Modelling (BIM) and Product Lifecycle Management (PLM) are more and more usable as the definition of a new way approaching the design and documentation managing of building projects. The presented computer aided design technology based on the concept of graphical - information modeling of a building, is combined with resource demand calculations, comparison of alternatives and determination of duration of all the stages of investment project life. The software based on this combined 4D PLM model is to be created as a means to manage effectively the investment project, starting from planning, designing, economical calculations, construction and afterwards to manage the finished building and to utilize it.
\end{abstract}

Keywords: Building Information Modelling, Computer Aided Design, Object Modelling Technique, Computer aided Construction estimating, Decision-Making Solutions.

\section{Introduction}

Over the last years, numerical object oriented product modeling and process simulation has evolved from a niche application to a fully accepted and widely used tool for product and process optimization. A growing product diversity, ever-increasing quality requirements, the rising pressure on cost and tighter deadlines, together with the technological enhancements, have been the driving force behind the universal breakthrough numerical simulation known in the recent past. The rapidly growing use of numerical simulation is due both to the constantly increasing hardware performance and to the methodical software enhancements. Thus, the user community has grown considerably in the recent past. Today, new challenges in view of a better integration of the simulation processes into the product development are arising. The objective is to accelerate the extraction of the knowledge accumulated in a wealth of simulations in such a way that it can be used to define product develop- ment standards and recommendations. It is becoming increasingly important to create efficient and effective simulation environments. The range of applications covers virtually every phase of the product development process. Long since, simulation systems have made their way to the designers' desks and an increasing number of users who have only little experience with simulation technology are using them for their daily work.

\section{BIM a new approach of the design and documentation of building projects}

With the growth of information technologies in the field of Construction industry, the concept of CAD (Computer Aided Design), which denotes just design operations using a computer acquires a new meaning and changes the contents lightening design process based on product modeling and further numerical simulation construction process and facility managing. New definitions as Building Informa- 
tion Modeling (BIM) and Product Lifecycle Management (PLM) are more and more usable as the definition of a new way approaching the design and documentation managing of building projects [1].

The concept Building Information Modeling (BIM) may be described as the way [2-5]:

- to develop the strategy of building project design, construction, and maintenance management based on the computer aided modeling and simulation technologies of the object and its development processes;

- to ensure the integrated management of graphical and information data flows enabling to combine virtual graphics (CAD) [6] with information flows (DB) and process descriptions, all this performing under a unified software environment;

- to transform individual executors into teams and decentralized tools into complex solutions, to integrate individual tasks into processes;

- to perform life cycle operations of a construction project faster, more effective, and with lower costs.

BIM is the driver with discipline-specific solutions, working together. By applying information and model-based technology solutions to allow the automatic generation of drawings and reports, design analysis, cost estimating, schedule simulation, facilities management, and more ultimately enabling the building team to focus on the information and their decisions, rather than the documentation tools and process. The result is a better way for building teams to work - with time saved, improved quality, and better buildings because of the informed decisions made along the way. Using BIM the entire lifecycle of the building is considered (design/build/operations). All information about the building and its lifecycle is included defining and simulating the building, its delivery, and operation using integrated tools. BIM integrates work, processes, and information for: multiple disciplines, multiple companies; multiple project phases.

In time aspect during design, there is increased opportunity for design iterations, as information is exchanged between disciplines quickly. Project documentation requires less time wasted on grunt work. Professionals can spend less time documenting decisions and more time making them. Everyone can avoid redundant effort. And construction can better support fast-tracking, tightly managed schedules, and the shared risks and rewards of design/build.

In quality aspect using BIM the user has improved coordination between documents, between disciplines, and across the entire team reduces errors and omissions. With coordinated documents and well-captured design intent, the enhanced design process makes for a far more informed design environment.

BIM provides at least two major advantages over CAD [7-9]:

- BIM models and manages not just graphics, but also information - information that allows the automatic generation of drawings and reports, design analysis, schedule simulation, facilities management, and more - ultimately enabling the building team to make better-informed decisions.

- BIM supports a managed environment so that people, tools, and tasks can effectively share this information throughout the building lifecycle, thus eliminating data redundancy, the need to re-enter data, data loss, miscommunication, and translation errors.

\section{Concept of object modelling technique}

The essence of BIM involves the fact that design is treated as an integral part of the building life cycle. Segmented work between the design parts and members is replaced by the adjusted process. This is achieved by changing the design technology substantially, switching from the development of a set of 2D drawings to the development of a 3D computer aided model of a building, comprising all the parts of the design, i.e. architectural, structural, mechanical, technological, construction process management, estimates, and etc.

In the design stage these goals are implemented by the technology of a Building continuum model, which focuses on the finally completed and fully equipped 3D building model comprising all the design parts. The base of this technology is made up of the 3D graphical-information model covering the following: building geometrical model; its physical properties (materials, etc.); functional peculiarities of its components.

One of the fundamental innovations of this technology includes component modeling. Previously computer design systems were adapted for the work of one user at data file level and as a result for isolation of this data from other users. The component modeling technology allows working in parallel with all design data at the level of data components covering the entire design cycle on the scale of a users group. Engineering components are graphical numerical models of real objects. These models characterize geometry, properties, links, and attributes of the real objects. It is assumed that a building consists of elements and parts different by their functions, properties, and manufacture technology. A part may involve a simple structural component (foundation, column, brick wall, floor slab, etc.) or a complex structure (multilayer wall, truss, composite plate, window, etc.). All elements or parts have specific 3D shape. In the drawing each element of this kind is marked and displayed adequately (line thickness, color, layer, hatching type, etc.). In addition, a user may assign for elements and parts other parameters characteristic of a real thing: material, its physical properties, class or standard, to link an 
element with technical specifications and descriptions, to assign for it tariffs and norms. This is done by using existing or developing one's own data structures.

All the graphical objects are 3D solids with the properties of the elements of real structures, they are parametrically controlled and intellectual, i.e. each object "knows" about itself both quantitative information (length, area, volume, and etc.) and qualitative information (material, contents), may preserve the development history and even "recognize" its developer. All this provide unlimited possibilities not only to develop objects, to change and edit the shape of objects rapidly and effectively, but also to preserve and manage their attributive information, using the $3 \mathrm{D}$ building model. In the meanwhile $2 \mathrm{D}$ information, i.e. different drawings (plans, sections, facades, details, and nodes) and other design documentation (list of materials, specifications, reports, and estimates) are generated from the 3D model.

Quantity and price of the specified components may be calculated by the measurement units required taking into account volume, area, length, or just by the parameter entered [10]. For instance, for the same wall the quantity of concrete or brickwork may be calculated by its volume; quantity of plaster, paint, wallpaper or finish tiles may be determined by the area of wall surfaces; quantity of trims, cornices, skirt boards may be measured by length, whereas quantities of reinforcement may be computed by the reinforcement percentage set.

Since these reports are linked to the model, new editions of the model update design data automatically. If necessary, external databases may be connected and used. Thus, accuracy, coordination, and synchronization of changes in the whole project documentation are ensured.

In principle new features of BIM concept are open for applying of virtual testing, and simulation of physical behavior of the model. That ensures by integration between 3D modeling systems and Finite Element Analysis (FEA) software applications for structural stress strain analysis nd design. Due to that possibility the succession between physical and analysis model maintains during information transition from modeling to analysis environment and back. Trends toward easy-to-use, integrated FEA software increase the potential benefits analysis can provide beyond traditional design validation to virtually every phase of product development, from concept development through physical prototyping and production.

Observing BIM application in design stage it can be accepted that of Object Modeling and Simulation Technique comprises a full range of actions starting from the development of virtual form or a model of the project under consideration (i.e. detail, structure, engineering system), describing all physical parameters characteristic of a real project (i.e. density, performances of strength and deformation, thermal constants, and etc.), defining the conditions of its position (i.e. supports, joint releases, interaction with other objects). Then analysis of model behavior under real maintenance conditions is performed: effects of different character (i.e. static and dynamic loads, temperature and humidity changes, wind pressure, and etc.) are described and the results obtained (reactions, internal forces, stresses, and deformed state) are analyzed. On the base of this analysis design solutions are made, design is performed, and search for optimal solutions is carried out. The results received by next step are presented in ordinary technical documentation form: drawings are generated, detailing of nodes and elements is performed, specifications and estimates are composed [11] (Fig 1).

Hence, modern computer technologies even in the design stage provide a possibility to treat a virtual model as a real object and to simulate all types of "true life" situation, see the result, always have the answer to the question: "what if...?". All this allows making right technical solutions in order to achieve the optimum result. The technology of computer aided design is based on the concept of building graphical - informational modeling in order to ensure the succession of the building design, its construction process and project maintenance management, to increase work efficiency and creativity, to provide the full engineering support cycle of a structure "from idea to a real object".

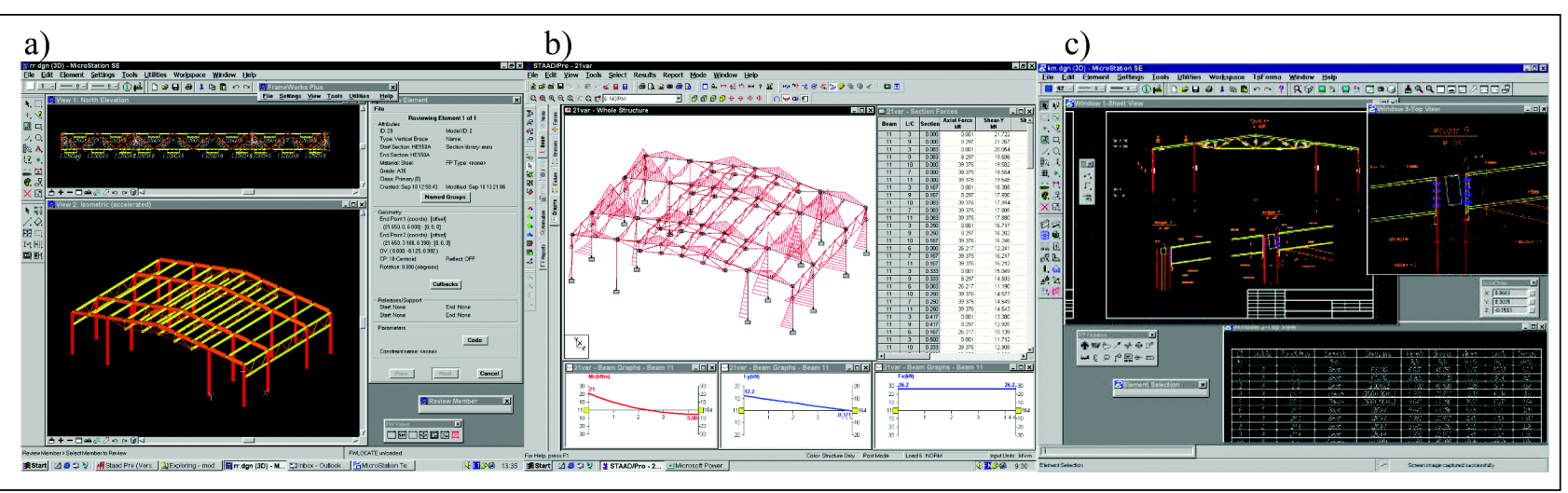

Fig 1. Three stages of project development using BIM concept: modeling (a); analysis (b); drawings and reports (c) 


\section{Price calculation of construction works and preparation of estimate documentation}

A significant share of design comprises (or at least shall comprise) evaluation of the economic part of a structure, first of all calculation of accurate (unbiased) price of construction (estimate). Usually an architectural-design part of a design is dissociated from an economic one strictly, therefore a designer (architect or constructor) having no tools and often even no possibilities (for instance, due to time restrictions) for unbiased pricing of a structure and comparison of variants, simply makes no price evaluation at all. Later, however, already after making a decision practically to construct exactly such a structure and after attempting to evaluate its price, it appears that the price differs substantially (usually it is higher) from the price supposed by the customer. Then it is necessary to look for more economical solutions, remake a design, and evaluate results once again, and so on.

Software for price calculation of construction and repair work as well as for the preparation of estimate documentation (EP) is designated for supporting the economic part of the design, i.e. for evaluating material and labor expenses and cost as well as specific work execution conditions. Usually this software has a double purpose: to schedule price of the works (and resources) planned and control the compliance with the plan scheduled. When forecasting the price of the works planned it shall be taken into mind what is the purpose of such actions, i.e. in order to achieve the result as soon as possible (e.g. when preparing material for a tender) or as accurate as possible (when preparing working estimates - tasks).

Traditionally an estimate maker, even having a specialized estimate program available, starts the work from "paper" drawings received as a result of the analysis carried out by designers. When reading the drawings an estimate maker notes down quantities of materials, analyses the constructional solutions used, determines whether the decisions made by the designer are in line with the effective economy criteria. Many of these actions duplicate the designer's work, i.e. an estimator shall grasp once again the material already known by the designer. When quantities and technological decisions in a design are known, estimate price calculation using EP is performed by selecting from the normative database corresponding norms (tariffs) of works, correcting them (adapting for a particular situation, specific conditions), regulating prices of materials, machinery, and labor.

Till now there were no attempts made in order to automate the process or propose measures enabling to price a structure (or its individual elements) interactively. In the meanwhile, integration of state-of-the-art computer aided design systems based on Object Modeling Technique (OM) and estimating software (EP) is possible by utilizing all available information and tools at the maximum (adjusting the effective interrelation between a designer and an estimator). It is one of the facets of Building Information Modeling (BIM) Technology. After solving these tasks the members of the design are provided with measures enabling to evaluate economic expenditures of a structure or its individual parts at the selected level of detailness, i.e. from "pure" material specifications to almost complete estimates, which consider labor force and all necessary additional materials, required machinery and imputations (e.g. remuneration of linear personnel, social taxes, profit, and etc.) [10].

This is the joint design worked out by the group of article authors intended for the solution of this problem. When implementing the design first of all the concept of the interrelation between a graphical - information model of a building and estimate has been formulated, technique for classifying constructional elements and materials has been generated, all necessary software tools and data structures have been developed:

- The database of typical articles (in other words, constructive elements or objects) and typical materials integrated into OM solves the problems of formal description of all elements and materials of a structure. Description of articles and materials by parameters facilitates the work of both a designer and an estimate maker significantly;

- The database of typical estimate fragments linked with the database of typical articles and materials allows automatic (software) selection of tariffs;

- Special EP modules enable to draw estimates of different detailness from OM specifications as well as to check the already drawn estimate with the specification and to highlight the changes.

The concept of the software for automated generation of estimates under BIM OM - ES environment is shown on principal scheme (Fig 2).

Implementation of the task set necessitated evaluating a very wide range of the related matters. All this has led to the need to create a unified classificatory of typical constructive elements (articles) and materials integrated to OM. The classificatory should enable a designer to describe constructive elements, to define their material composition in order to ensure homologous understanding of this material (a 3D model, drawings, specifications) by other members of the design, i.e. estimate makers, technologists.

It was necessary to solve the selection of estimate fragments in order to evaluate the implementation (execution) works of a typical element. An estimate fragment means a group of norms defined by parameters and linked. In other words it is a parametrical estimate including all the necessary works and resources depending on design technological properties of a construction element. For all these fragments particular quantities and norms depend on characteristic parameters, e.g. geometry, materials, technology, and etc. Parameters are defined when generating the structure 
model based on BIM and passed to EP. Same as OM, EP also have tools enabling user to expand and detail classificatory, to develop typical articles and fragments itself, therefore each user may adapt a general concept for its own needs.

Classificators are the main facet and essential subject of BIM and EP integration. Ordered description of constructive elements is necessary for automated selection of fragments and prices. By using classificators it is possible to develop fully functional bases of design elements and typical materials, to link design elements with construction technology at the level of desired detailness (to select work norms), etc. In this case as one of variants the following classificators may be used: "Vysshije klasifikacionnye grupirovki otraslevogo kataloga produkcii" (ВКГОКП) for describing typical materials [12]; "Klasifikator rabot i uslug v stroitelstve" (OKPУC) for describing typical design elements (linking with construction technology) [13].
Even in a case of a relatively complicated model, estimates are generated rapidly, therefore a designer may adjust a model (or its individual parts only) interactively and follow price changes. Surely, a designer may use in the design not typical constructive elements and these elements in the estimate will appear only in a "material" form, i.e. without the work necessary for their implementation and without additional resources. In any case, however, an estimate maker from the estimate generated using the program shall prepare a real (final) estimate, i.e. shall adjust prices finally, enter additional works or remove unnecessary ones, if required, etc. After such adjustment an estimate may differ from the initial one, however, observing certain rules a designer does not loose a possibility to recalculate an estimate later in case a model (quantities of materials, materials themselves, and etc.) changes: ES tools enable to "check" an existing estimate with the changed model.

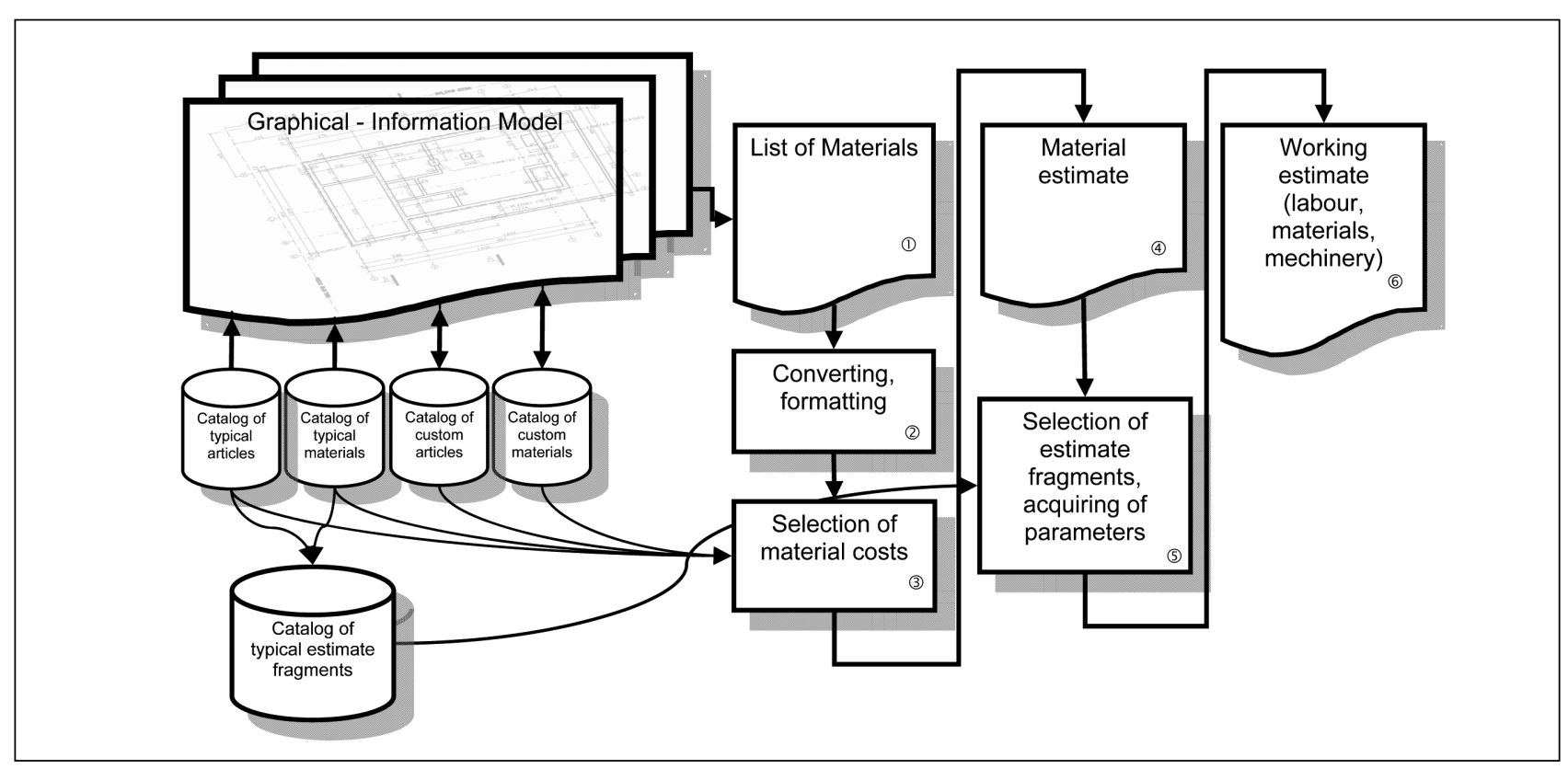

Fig 2. Diagram illustrating automated generation of estimates under BIM OM - ES environment

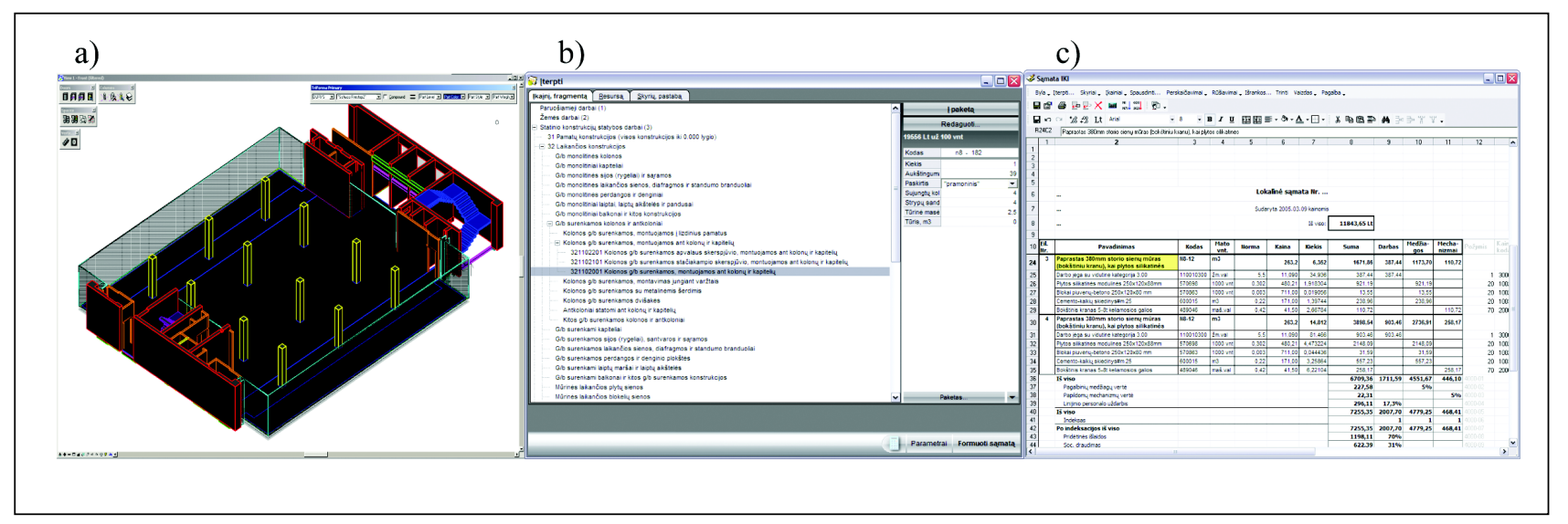

Fig 3. Three stages of of SAS: modeling (a); parametrization of building elements (b); estimating (c) 


\section{Computer aided construction estimating system}

SAS - Computer aided construction estimating system, based on Building Information Modelling concept, interconnects structural design, estimating and time scheduling. The main purpose of SAS is to automate the economic part of design the maximum, providing user (designer, contractor or investor) with possibility to evaluate economic expenditures at any stage of a project - from the design to finished construction. Just-one-click tools enables user to get an estimate (expenditures of resources, supposed operations, cost calculations) with no need to calculate quantities, select work normatives, evaluate conditions - everything is obtained automatically from information model of a construction [10]. An estimate is obtained in a file format of SES2004, and can be edited using the widest functionality of this application and largest databases of wok norms and construction resources (materials, labor, machinery) [911]. As there are references between constructional element (in a model) and estimate, one can acquire any cost-related and expenditure-related information for each such element using detail description of typical elements (TE). Changes in a design can automatically regenerate associated estimate. All information about operations and resources from estimate can be passed to time scheduling applications, such as Microsoft Project. All information is stored in a general database, so feedback is widely possible.

SAS Database of typical constructional elements (DTCE) is oriented to topical up-today solutions in con- struction. The basis of DTCE database is Classificator of typical constructional elements (CTCE), which arranges typical elements into classes, groups and subgroups according to technological processes. Each description of typical element contains code, name, set of parameters, fragment of estimate and a macro, which process fragment depending on parameters (for example, chooses appropriate norms, calculates quantitative information, etc.). Fragments of estimates for typical elements are based on norms, certified by governmental institutions of Lithuania and Russian Federation. DTCE database can be easily updated by new elements, adapted to any company, it's technology. On purpose to ease the setting of parameters, most of values can be picked from a list; along with numerical parameters, DTCE provides proper versatility.

According to carried calculations, this system can save up to 40 percent of the time, required for design and economic-technologic calculations, including preparation of drawings, estimates, schedules and analyzing a number of alternative versions of a project.

\section{Determination of an effective variant}

Having analyzed the characteristics of the construction project and applied the PLM concept, a model suitable for determining a precise most effective variant is developed for construction project automated management within its entire life (Fig 3) [11]. Data of each block after the ac-

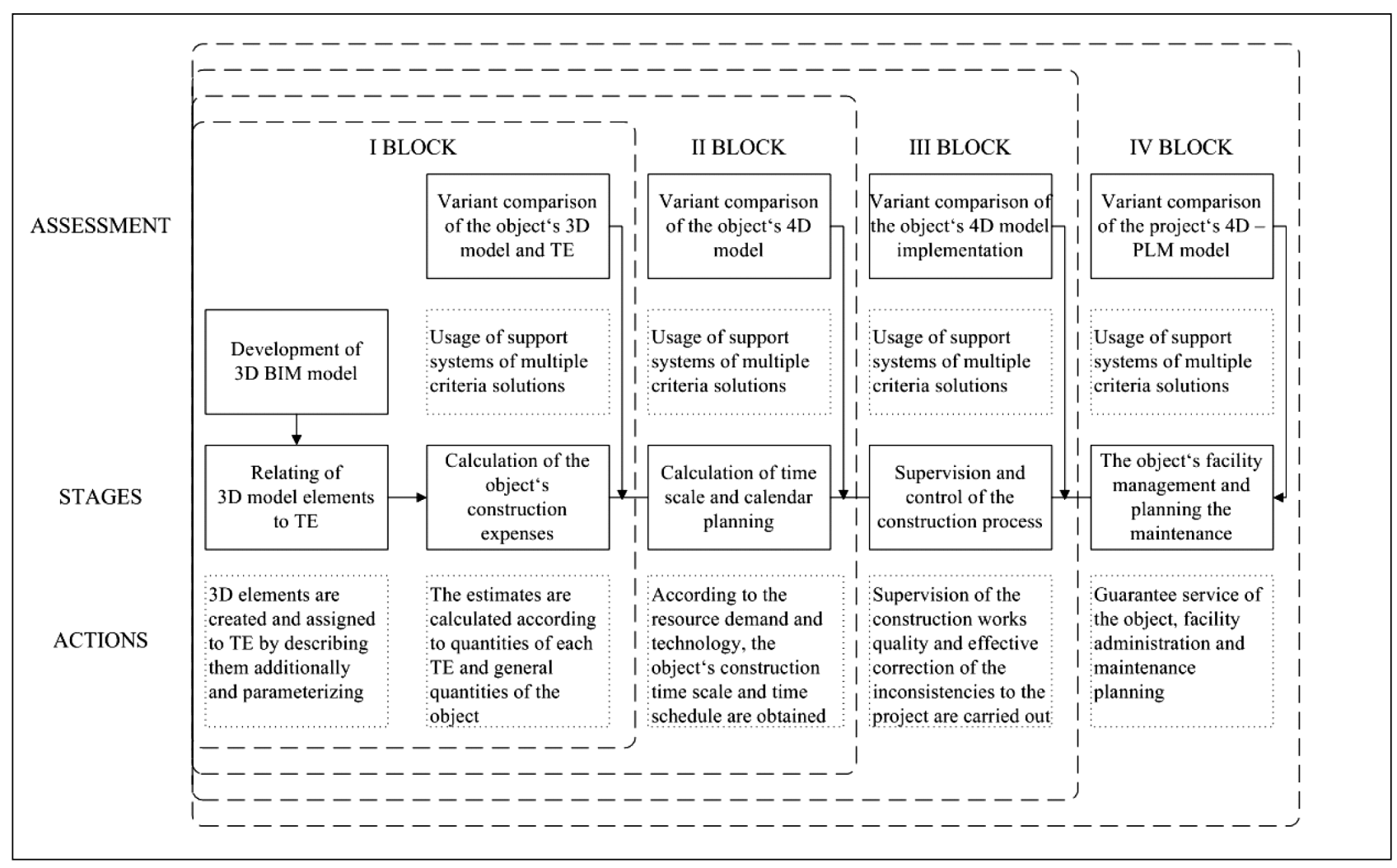

Fig 4. Model of the construction project automated management within its entire life 
complishment of every stage can be analyzed comparing the selected alternative variants, and the collected information can be transferred to the next block. In this way a flexible simulation and real time analysis are obtained, with the help of which in case there are any changes in the situation (at any stage of the project implementation cycle) alternative solutions can be assessed and the most effective variant at that time chosen using PLM concept and virtual 3D BIM model data.

As it is shown in Fig 4, it is available to compare (assess) the alternative solutions or evaluate the alternative variants in each block of the model. In this stage it is advisable to use multiple criteria evaluation methods. In construction indicators of the implemented designs are different from those calculated according the design and drafts. The existence of information lack does determine the unreliable or incomplete information. When these uncertainties are caused by random effects defined by evaluations according to the distribution laws set by various statistical methods, then we have the problems of stochastic indefiniteness. For decision making under the conditions of uncertainty the game theory methods may be applied [11].

The professors of Vilnius and Leipzig high schools have been performing a research into the problem of multiple criteria evaluation and uncertainty for several years. They were analyzing the usage of mathematical-statistical methods for multiple criteria evaluation and have applied game theory to solve uncertainty problem. Using LEVI 3.0 software (Peldschus, Zavadskas, Ustinovichius et al.) [14] it is possible to find solutions for a task by means of different methods, to compare the construction project variants by choosing the solutions and choose the economically effective variant in construction.

\section{Conclusions}

1. In order to characterize modern information technologies in the field of computer aided design the notion of BIM (Building Information Modeling) is used, the concept of which may be defined by the following goals: to develop the strategy of construction project design, its construction, and maintenance management, based on computer aided modeling technologies of the object and its development processes; to ensure the integrated management of graphical and information data flows, enabling to integrate virtual graphics with information flows and process descriptions, all this performing under a unified software environment; to transform individual executors into commands, decentralized tools into complex solutions, to integrate individual tasks into processes; to perform life cycle operations of a construction project faster, more effective, and with lower cost.

2. BIM technology is based on the concept of static graphical - information modeling, the essence of which involves the fact that a design is treated as an integral part of the building life cycle. Segmented work between the design parts and members is replaced by the adjusted process. This is achieved by changing the design technology substantially, switching from the development of a set of $2 \mathrm{D}$ drawings to the development of a $3 \mathrm{D}$ computer aided model of a building, comprising all the parts of the design, i.e. architectural, structural, mechanical engineering, technological, estimates, and etc.

3. Integration of state-of-the-art computer aided design systems based on Object Modeling Technique (OM) and estimate programs (EP) enables to evaluate the prices of a structure (or its individual elements) interactively.

4. The concept of the relation between a graphical - information model of a building and estimate has been formulated; technique for classifying design elements and materials has been generated, necessary programming tools and data structures have been developed; integration of $\mathrm{OM}$ and EP systems has been performed; technique for computer aided evaluation of economic indicators of a construction project has been composed.

5. SAS - Computer aided construction estimating system, based on Building Information Modeling concept, interconnects structural design, estimating and time scheduling. The main purpose of SAS is to automate the economic part of a design the maximum, providing a user (designer, contractor or investor) with the possibility to evaluate economic expenditures at any stage of a project - from the design to finished construction.

6. The advantage of the whole PLM concept is a possibility to simulate the management of the project, on the basis of 3D model to calculate the precise resource demand, to determine the time scale of the project implementation and to assess effectively alternatives. It is suggestible to use the multiple criteria decision support software LEVI 3.0 as evaluation tool to choose effective construction project alternative group.

\section{Literature}

1. Ford, S.; Aouad, G.; Brandon, P.; Brown, F.; Child, T.; Cooper, G.; Kirkham, J.; Oxman R.; Young, B. The object oriented modelling of building design concepts. Building and Environment, Vol 29, No 4, 1994, p. 411-419.

2. Popovas, V.; Jarmolajevas, A.; Grigorjeva, T. State-of-the-art computer aided design systems. Nauja statyba, No 6, 2003, p. 26-29; No 7, 2003, p. 40-41 (in Lithuanian).

3. Hoekstra, J. Big Buzz for BIM. Architecture, Vol 92, No 7, 2003, p. 79-82.

4. Gabbar, H. A.; Aoyama, A.; Naka, Y. Model-based computeraided design environment for operational design. Computers \& Industrial Engineering, Available online 5, 2004. 
5. Brown, F. E.; Cooper, G. S.; Ford, S.; Aouad, G.; Brandon, P.; Child, T.; Kirkham, J. A.; Oxman, R.; Young, B. An integrated approach to CAD: modelling concepts in building design and construction. Design Studies, Vol 16, No 3, 1995, p. 327-347.

6. Ford, S.; Aouad, G.; Kirkham, J.; Brandon, P.; Brown, F.; Child, T.; Cooper, G.; Oxman, R.; Young, B. An information engineering approach to modelling building design. Automation in Construction, Vol 4, No 1, 1995, p. 5-15.

7. Narmontas, D.; Popovas, V. Development of integrated design and analysis systems. In: Works of technology science in western Lithuania, Klaipeda, 2000, p. 112-113 (in Lithuanian).

8. Garner, B.; Raban, R. Context management in modeling information systems (IS). Information and Software Technology, Vol 41, No 14, 1999, p. 957-961.

9. Mikalauskas, S.; Popovas, V. SES 2000 - Automated Estimation in TriForma environment. Nauja statyba, No 10, 2003, p. 33-35 (in Lithuanian).

10. Popovas, V.; Ustinovichius, L.; Mikalauskas, S. Technique for computer aided evaluation of economic indicators of a con- struction project. In: The 8th International Conference "Modern building materials, structures and techniques", Selected papers (May 19-21, Vilnius, VGTU), 2004, p. 242-248.

11. Ustinovičius, L.; Popov, V.; Migilinskas, D. Automated management, modelling and choosing of economically effective variant in construction. Transport and Telecommunication. In: Proceedings of International Conference "RelStat'04", Transport and Telecommunication Institute, Riga, Latvia, Vol 6, No 1, 2005, p. 183-189.

12. Higher classification groups of production branch catalog (VKGOKP) (Высшие классификационные группировки отраслевого каталога продукции (ВКГОКП)). Moscow: "Statistics", 1976.

13. Glossary of works and services in construction (OKRUS) (Классификатор работ и услуг в строительстве (ОКРУС)), Gosstroj USSR, Moscow, 1987.

14. Zavadskas, E. K.; Peldschus, F.; Ustinovichius, L. Development of software for multiple criteria evaluation. Informatica, Vol 14, No 2, 2003, p. 259-272.

\title{
4D INFORMACINIO MODELIAVIMO KONCEPCIJOS KOMPLEKSINIS TAIKYMAS STATINIAMS PROJEKTUOTI, SĄMATAI İVERTINTI, KALENDORINIAM PLANAVIMUI IR VARIANTAMS PALYGINTI
}

\author{
V. Popov, S. Mikalauskas, D. Migilinskas, P. Vainiūnas
}

\section{Santrauka}

Besivystant informacinėms technologijoms kompiuterinio projektavimo srityje, sąvoka CAD igyja naują prasmę ir keičia turini, išryškinamas projektavimo procesas, pagristas projektuojamo objekto modeliavimo ir jo tolesnio statybos proceso ir turto valdymo virtualaus imitavimo technologijomis. Naujos sąvokos: Building Information Modeling - statinio informacinis modeliavimas (BIM) ir Product Lifecycle Management - produkto gyvavimo ciklo valdymas (PLM), taikomos naujam požiūriui i objekto projektavimo ir dokumentų valdymo procesą apibrěžti. Siūloma kompiuterinio projektavimo technologija grindžiama statinio grafinio-informacinio modelio sukūrimo koncepcija, kuri savo ruožtu yra suderinta su išteklių poreikio skaičiavimais, alternatyvų lyginimais ir investuojamo projekto etapų gyvavimo trukmès nustatymu. Specializuota programinè įranga šiam kombinuotam 4D PLM modeliui sukurti naudojama, kai reali priemone efektyviai valdyti investuojamą projektą, pradedant planavimu, projektavimu, ekonominiais skaičiavimais, statybos organizavimu, baigiant pastato valdymu ir utilizavimu.

Reikšminiai žodžiai: statinio informacinis modeliavimas, kompiuterinis projektavimas, objektinio modeliavimo technologijos, automatizuotas ekonominis įvertinimas, sprendimų paieškos sistema.

Vladimir POPOV. Doctor, Associated professor. Department of Reinforced Concrete and Masonry structures, Vilnius Gediminas Technical University. Diploma Engineer of Civil Engineering, VISI, now VGTU (1981), PhD (1990), Associated Professor (1993), Author of over than 80 publications (research results, study guides and projects). Author of 5 patented inventions., Research interests: Theory of reinforced concrete, computer aided analysis and design methods and techniques for structural design.

Saulius MIKALAUSKAS. „Statybos ekonominiai skaičiavimai“ AG, Lithuania. First degree in Applied mathematics, KTU (1997), MSc (1999).

Research interests: estimation of construction cost and expenditures, voice recognition.

Darius MIGILINSKAS. PhD Student. Department of Construction Technology and Management. Vilnius Gediminas Technical University. First Degree in Civil Engineering VGTU (2001), MSc (2003). Research interests: multi criterion analysis, determining of efficiency of investments and construction.

Povilas VAINIŪNAS. Doctor, Professor. Dean of Civil Engineering Faculty at Vilnius Gediminas Technical University, Vilnius, Lithuania. PhD (1970) from Kaunas Politechnical Institute (presently Kaunas Technological University). Chairman of national group of International Association for Bridge and Structural Engineering (IABSE). Former vice-president (1992-95) and board member (since 1995) of Association of European Civil Engineering Faculties (AECEF). Chairman of scientific committee of biennial intern. conference „Modern building materials, structures and techniques“ held at VGTU, Lithuania. Author and co-author of over 70 research papers. Research interests: mechanics of reinforced concrete, theory of durability and reliability, design of buildings, development of territory planning and building coder system of Lithuania and real estate assessment. 